\title{
CHARACTERISTIC OF AUDITOR IMPACT TO AUDIT DELAY IN COMPANY LISTED IN BURSA EFEK INDONESIA
}

\author{
Santi Yopie
}

Universitas Internasional Batam, Indonesia

Corresponding author: santi.yopie@uib.ac.id

\begin{abstract}
The purpose of this study is to determine the characteristic auditor impact to audit delay. In this study the characteristic auditor is using audit committee size, audit committee meeting and audit committee expertise. The sample of this study is the companies which listed in Bursa Efek Indonesia and publish the annual report and audited report for the period of 2015-2019. Researchers used purposive sampling method, in which the research sample was not taken randomly but was based on aspects of consideration that were in accordance with the research objectives. The use of the purposive sampling method in this study was carried out by selecting companies which published annual report and audited financial report during the period year of 2015 to 2019. The research data were analyzed through multiple regression analysis using Eviews. The result of study showed that audit committee size and audit committee expertise has no significant effect to audit delay. The audit committee meeting has significant effect to audit delay. The contribution of this study is exploration the causes of audit delay for giving companies aware and prevent any audit delay which can cause costly penalty.
\end{abstract}

Keywords: Audit Committee Expertise, Audit Committee Size, Audit Committee Meeting, Audit Delay

\section{Introduction}

In current market conditions, business competition has become increasing fiercely, requiring companies to be even more competitive in carrying out their business activities. To face this competition, the information disclosed in financial reporting must be complete, clear and useful and should not confuse users because they are involved in making economic decisions. Financial reports serve to convey financial information on the company in a certain period. Financial reports must also be up to date and reliable, timeliness and accurate (Ahmed \& Che-Ahmad, 2016). The timeliness of financial reporting is very important in order to make decisions for its users in terms of analyzing within the economic factor (Kurniawan \& Laksito, 2015). The company who listed in Bursa Efek Indonesia must publish an audited financial report. Auditors are required to complete the audit process with high quality audit report. The duration of audit processing time will reflect in an appropriate standard. The timeliness of the auditors in the audit process reflects the quality and professionalism of the auditors themselves. Due to the timeliness of completing the audit process within the specified time, it determines the speed of the company to publish financial reports to the public. Audit Delay or Audit Report Lag is the time period used by the company in completing the audit on company reports which is determined from the closing date of the financial year to the date of issuance of the auditor's repor (Abdillah, Mardijuwono, Habiburrochman, 2019).

Timeliness is an essential qualitative characteristic of accounting and a fundamental element of the relevance of financial reporting information in developing market economies. Timeliness in reporting, in the absence of publicly available financial reporting information, remains largely, the only way in which outside shareholders and investors remain informed about company performance (Muchran, 2016). Timeliness of financial reporting is very important for the functioning of the capital market because it reduces asymmetry in information and increases the usefulness of decisions in information (Vuko \& Čular, 2014). Audit report delay, namely the delay in completing the annual financial statement audit activities with measurements based on the number of days spent finalizing or completing the audit of the company's annual financial statements by the auditor (Hapsari, Putri \& Arofah, 2015).

According to the General Guidelines for Good Corporate Governance in Indonesia (2006), financial reports must be ensured by the audit committee and then presented appropriately according to applicable accounting principles where they ensure the company's internal structure is well controlled. If the audit committee can guarantee that the company's internal control is carried out properly, then the risk of financial delivery errors will be low along with low control risk. The audit committee has the task of monitoring the planning, implementation and evaluation of audit results, to provide a feasibility assessment and internal control, including overseeing the process of making financial reports (Lestari \& Nuryatno, 2018). Khoufi and Khoufi (2017) states that the audit committee size has a significant positive effect on audit delay in Nigeria. However, some research do not show a significant effect between audit committee size on audit reporting delay (Apadore \& Mohd Noor, 2013; Setiawan \& Nahumury, 2014; Faishal \& Hadiprajitno, 2015; Frischanita, 2018).

One of the audit delay case in the companies who listed in Burse Efek Indonesia is happened in early year of 2013. There has four companies is received the warning letter regarding the audit delay. The normal 
penalty is around $\mathrm{Rp} 50$ Million to Rp 150 Million. Three of them (PT. Dayaindo Resources International Tbk, PT Davomas Abadi, Tbk, and PT. Buana Listya Tama, Tbk) is received the 3rd level warning letter which need to additional penalty of Rp 150 Million. Another one (PT. Berlian Laju Tanker) is received the 2nd level warning letter which additional penalty Rp 50 Million (Aditiasari, 2013). These cause the audited financial report is late to publish to public based on the required deadline. In this case, it showed that there has something wrong in internal which caused audit delay.

Audit committee meetings aim to update information and understanding regarding accounting issues facing in the company. With the existence of an audit committee meeting, it is expected to be able to provide direction on solutions to financial problems in a timely manner (Mahendra \& Widhiyani, 2017). Nehme, Nehme, Assker and Khalife (2015) explain that this variable has a significant positive relationship to audit delay. Results equivalent to this study were obtained in research conducted by Shukeri and Islam (2012), Faishal and Hadiprajitno (2015). However research by Hashim and Rahman (2012), Apadore and Mohd Noor (2013), and Mahendra and Widhiyani (2017) found that the audit delay was not influenced by the number of audit committee meetings.

The audit committee has an obligation to carry out duties and activities related to accounting, which is required to understand accounting and the problems and risks that will arise in the process (Frischanita, 2018). companies with audit committee members who are less likely to commit fraud due to experience and expertise in accounting. An audit committee can be declared if there is work ability and deep understanding in the field of finance, and has accounting degrees such as MIA (Master of International Affairs), ACCA (Association of Chartered Certified Accountants), CPA (Certified Public Accountant), and others, as well as an accountant (Apadore \& Mohd Noor, 2013). Audit committees that tend to better understand and control the risks and the timeframe for conducting an audit using the audit method are committees that are more capable and expert in accounting processing. When there is a disagreement of opinion or response between management and the external auditor, the experienced audit committee plays a role in understanding the audit statement (Yadirichukwu \& Emibomowei, 2013). A study in Tunisia regarding the effectiveness of the experience audit committee having a significant negative effect on audit delay (Sahama \& Khlif, 2017). Handayani and Yustikasari (2017) explain that there is a significant positive influence between the audit delay and audit committee expertise. However, research Shukeri and Islam (2012), Apadore and Mohd Noor (2013) yielded different explanations, where between the audit committee expertise has no significant impact to audit delay. Based on the background and gaps from previous studies, the research model and hypothesis proposed in this study are.

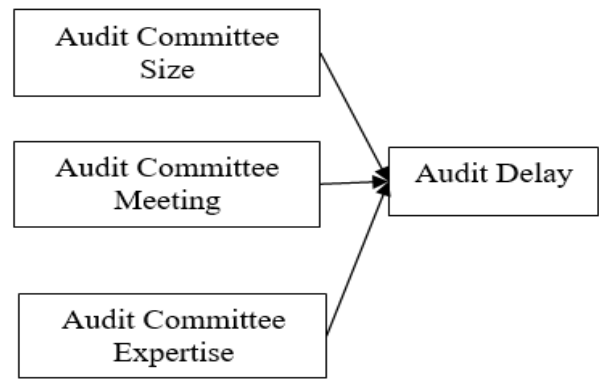

Figure 1. Conceptual Framework

H1 : Audit Committee Size has a significant effect on audit delay.

H2 : Audit Committee Meeting has a significant effect on audit delay.

H3 : Audit Committee Expertise has a significant effect on audit delay.

\section{Research Method}

Researchers used purposive sampling method, in which the research sample was not taken randomly but was based on aspects of consideration that were in accordance with the research objectives. The use of the purposive sampling method in this study was carried out by selecting companies which published annual report and audited financial report during the period year of 2015 to 2019. Audit delay is measured by duration days between the closing period to audited report is published. Audit committee size is measured by total number of audit committee in company. Adit committee meeting is measured by frequency of meeting in audit committee department. Audit committee expertise is measured by number of audit committee who own qualification and professional in finance and accounting (Raweh, Kamardin, Malik, 2019).

\section{Result and Discusssion}

Total observation data is 1.689 data which consist of 432 companies from year of 2015-2019 and the outlier data is 39 data. Based on the descriptive analysis, average size of audit committee is consist of 3 person, it is already meet the minimum requirement of regulation no 8/14/PBI/2006 which required minimum 3 person. There is only $23 \%$ member of audit committee has owned expertise in finance and accounting and 
having meeting frequency 7 times per year. The audit delay has average 79 days (around 2-3 months) means that normally those companies is fulfill the requirement which need to publish the audited report latest by April.

Based on the t test, the effect of audit committee size (sig. 0.1753) and audit committee expertise (sig. 0.6730) has no significant effect to audit delay, and the frequency of audit committee meeting (sig. 0.0447) has significant effect to audit delay. Audit delay is no significant impacted by audit committee size because audit committee member still cannot prove that they able to make decision and fulfill obligation which required from regulation by Financial Services Authority (OJK) to monitor and evaluate the effectivity of internal control and preparation of financial report. A company who owed more or less member of audit committee cannot reflect the effectivity of internal control. Some of them just only for formality as fulfill the requirement from OJK which will not bring any effect in audit delay (Ishaq \& Che-Ahmad, 2018; Yadirichukuwu \& Emibomowei, 2013). Audit committee expertise bring no effect to audit delay because of some of them maybe own the qualification but may not implement the competencies as well in their duties (Handayani \& Yustikasari, 2017). Audit committee meeting bring significant effect on audit delay because of the more frequent of meeting the more delay of audit. Audit committee meeting can bring positive effect to control the progress if the frequency is optimal (Nehme, et al. 2015), it will delay the audit report if too much bureaucracy.

\section{Conclusion}

The purpose of this study is to analysis the effect of audit characteristic to audit delay. The result show that audit committee size and audit committee expertise have no significant effect to audit delay. The audit committee meeting has significant effect to audit delay and has positive influence. In Indonesia, there has regulation that set the requirement for audit committee board. Many of them only set the audit committee to fulfill the requirement but not fully implement so it bring no significant effect to audit delay.

For further research may consider to analysis the function of audit committee in implementing the daily duties. It maybe can use the interview session which can provide more valuable result in this scope of studies. It also can compare the audit characteristic between Indonesia and the country which already have good corporate governance to make a comparison analysis.

\section{References}

Abdillah, M. R., Mardijuwono, A. W., \& Habiburrochman, H. (2019). The effect of company characteristics and auditor characteristics to audit report lag. Asian Journal of Accounting Research, 4(1), 129-144. https://doi.org/10.1108/ajar-05-2019-0042

Aditiasari, D. (2013). Telat serahkan laporan keuangan, 4 emiten didenda. Diakses dari: https://ekbis.sindonews.com/berita/706114/32/telat-serahkan-laporan-keuangan-4-emiten-didenda

Ahmed, M. I., \& Che-Ahmad, A. (2016). Effects of corporate governance characteristics on audit report lags. International Journal of Economics and Financial Issues, 6(7Special Issue), 159-164.

Apadore, K., \& Mohd Noor, M. (2013). Determinants of Audit Report Lag and Corporate Governance in Malaysia. International Journal of Business and Management, 8(15), 151-163. https://doi.org/10.5539/ijbm.v8n15p151

Faishal, M., \& Hadiprajitno, P. B. (2015). Pengaruh mekanisme good corporate governance terhadap audit report lag. Diponegoro Journal of Accounting, 4(4), 1-11.

Frischanita, Y. (2018). A comparative study of the effect of institutional ownership, audit committee, and gender on audit report lag in Indonesia, Malaysia, and Singapore. The Indonesian Accounting Review, $8(2), 131-143$.

Handayani, Y. D., \& Yustikasari, Y. (2017). Corporate governance and audit report lags at manufacturing companies in the industrial sector of consumption goods. European Journal of Business and Management, 9(29), 24-32.

Hapsari, A. N., Putri, N. K., \& Arofah, T. (2016). The influence of profitability, solvency, and auditor's opinion to audit report lag at coal mining companies. Binus Business Review, 7(2), 197-201.

Hashim, U. J., \& Rahman, R. A. (2012). Internal corporate governance mechanisms and audit report lag: A study of Malaysian Listed Companies. Corporate Board: Role, Duties \& Composition, 8(3), 48-63.

Khoufi, N., \& Khoufi, W. (2017). An empirical examination of the determinants of audit report delay in France. Managerial Auditing Journal, 33(8), 700-714.

Kurniawan, A. I., \& Laksito, H. (2015). Analisis faktor-faktor yang mempengaruhi audit delay(Studi Empiris pada Perusahaan LQ 45 yang Terdaftar di Bursa Efek Indonesia Periode Tahun 2010 - 2013). 4(3), 319331.

Lestari, S. Y., \& Nuryatno, M. (2018). Factors affecting the audit delay and its impact on abnormal return in Indonesia Stock Exchange. International Journal of Economics and Finance, 10(2), 48.

Mahendra, A. A. N. P., \& Widhiyani, N. L. S. (2017). Pengaruh GCG, opini auditor dan internal auditor terhadap audit delay pada perusahaan telekomunikasi di BEI. 21(2), 1601-1629. https://doi.org/10.24843/EJA.2017.v21.i02.p27 
Muchran, M. (2016). Effect of company size, and financial ratio on audit report lag. Qualitative and Quantitative Research Review, 1(2), 122-138.

Nehme, R., Assaker, G., \& Khalife, R. (2015). Dynamics of audit lag - Board of directors and audit committees' effect. Corporate Ownership and Control, 12(3CONT3), 281-294. https://doi.org/10.22495/cocv12i3c3p1

Raweh, N. A. M., Kamardin, H., \& Malik @ Malek, M. (2019). Audit Committee Characteristics and Audit Report Lag: Evidence From Oman. International Journal of Accounting and Financial Reporting, 9(1), 152. https://doi.org/10.5296/ijafr.v9i1.14170

Samaha, K., \& Khlif, H. (2017). Audit-related attributes, regulatory reforms and timely disclosure: Further evidence from an emerging market. Journal of Financial Reporting and Accounting, 15(2), 158-179.

Setiawan, G., \& Nahumury, J. (2014). The effect of board of commissioners, audit committee, and stock ownership concentration on audit report lag of banking companies in Indonesia Stock Exchange. The Indonesian Accounting Review, 4(01), 15. https://doi.org/10.14414/tiar.v4i01.280

Shukeri, S. N., \& Islam, M. A. (2012). The determinants of audit timeliness: Evidence from malaysia. Journal of Applied Sciences Research, 8(7), 3314-3322.

Vuko, T., \& Čular, M. (2014). Finding determinants of audit delay by pooled OLS regression analysis. Croatian Operational Research Review, 5(1), 81-91. https://doi.org/10.17535/crorr.2014.0030

Yadirichukwu, E., \& Emibomowei, A. (2013). Audit Committee And Timeliness Of Financial Reports: Empirical Evidence From Nigeria. Issn, 4(20), 2222-1700. www.iiste.org 